Resubmitted following referees' suggestions, 5 June 2017. Accepted 10 August 2017.

'Accepted Version' for publication in The International Journal for Art \& Design Education (In Press 2017)

\title{
Drawing as Driver of Creativity: Nurturing an Intelligence of Seeing in Art Students
}

Howard Riley PhD MA(RCA) CertDes FRSA FHEA

Emeritus Professor, Swansea College of Art, University of Wales Trinity Saint David

howard.riley@btinternet.com

ORCiD id: orcid.org 0000-0002-8682-2587

\begin{abstract}
The article re-asserts the primacy of drawing as a driver of creativity within art schools. It reviews specific aspects of visual perception theory and visual communication theory relevant to a pedagogical strategy as a means of nurturing an intelligence of seeing in art students. The domain of drawing is theorised as a systemic-functional semiotic model informed by Michael Halliday's model for language, as adapted by Michael O'Toole in his 2011 The Language of Displayed Art. The model is demonstrated as an aid to the production of drawings, rather than its more recognised efficacy as a means of negotiating meaning from existing works. The article is illustrated with examples of drawings by the author.
\end{abstract}

\section{Keywords}

Drawing; Pedagogy; Intelligence of Seeing; Modes of Perception; Systemic-Functional Semiotics.

\section{Introduction}

To begin at the beginning... why are students' early, untutored attempts at depiction always without scenic background and mostly in outline? These traits are noticeable in the early cave drawings too, analysis of which has led John Halverson (1992: 389) to suggest:

The answer seems to lie within certain fundamental features of visual perception: figure-ground distinction, Gestalt principles of closure and good continuation. These evoke the same visual responses as those involved in the perception of real-world forms, but eschew redundancies of colour, texture, linear perspective and completeness of representation.

He elaborates:

The pictorial outline abstracts from the silhouette its only signifying feature, its occluding edge, or better, its "occluding bound" (Kennedy and Silver 1974). Thus, although an unnatural artifact, the pictorial outline successfully exploits a fundamental component of natural object perception. (Halverson 1992: 391). 
Such an innate mode of transformation from 3-D scene to 2-D representation is at the root of our facility for drawing. However, we have come to understand that our visual perception processes can be - are - influenced by our various cultural contexts (Husserl 1970 [1913]; Jakobson 1960; Segall et al. 1966).

Arthur Koestler (1975: 376-377) summarises:

Perception is a part-innate, part-acquired skill of transforming the raw material of vision into the 'finished product'; and every period has its conventional formulae and methods of interpretation for doing this. The ordinary mortal thinks most of the time in clichés - and sees most of the time in clichés. His (sic) visual schemata are prefabricated for him; he looks at the world through contact lenses without being aware of it.

It is clear that the facility for drawing, the fundamental driver of visual creativity, defined here as the ability to free ourselves from our culturally-conditioned perceptions in order to construe a variety of constructions of reality, requires nurturing. The problem for teachers of drawing is how to structure a pedagogy which delivers an increased level of what has been called an intelligence of seeing (Riley 2008). This article offers a strategy based upon theoretical bases fundamental to the activity of drawing: the theoretical bases of visual perception and visual communication.

\section{A Review of Theoretical Bases: Two Components of an Intelligence of Seeing}

Drawing, properly taught, is the best way of developing intelligence and forming judgement, for one learns to see, and seeing is knowledge. (Viollet-le-Duc 1879: 305)

The concept intelligence of seeing can be understood as a cultural superstructure built upon two of the natural, basic human activities crucial to survival since Palaeolithic times, some 30,000 years ago (Halverson 1992: 389); firstly, the perceiving of our environment and our individual positions within it, and secondly, the social need to share - communicate - those perceptual experiences in a visual form, as demonstrated by the early cave drawings. A first indicator of an intelligence of seeing would be evidence of a versatility of vision which 
transcends Halverson's ‘fundamental features of visual perception'; a versatility informed by an awareness of how to change channels, as it were, so as to extract different levels of information from the scene observed. A second indicator would be evidence of an ability to communicate through drawing practice a range of drawn equivalences for the perceptual experiences, relevant to the aims of the drawing: to convey the response of the drawer as well as the positioning of viewers, in terms of their mood and attitude towards the subject matter represented in the work.

\section{Perception}

A way of picturing involves the appropriation of a way of seeing.

(Witkin 1995: 62 italics in original)

From the insights of visual psychologist James J. Gibson (1979), who advocated an ecological approach to the understanding of visual perception which theorises how our sensesystems, including vision, have evolved to resonate with the energy fields of our environment in order to pick up information upon which we act to survive, it is possible to theorise that various levels of visual information about our environment and our position within it, contained in the structure of the light arriving at the eyes, can be accessed through the various ways of seeing - modes of perception - available to the student:

Proximal mode: what we notice about the pattern structure which makes up the overall visual field.

Distal mode: what we notice about distance, depth and spatial relations between surfaces and edges within the scene observed.

Haptic mode: what we notice about textural qualities of surfaces we observe. Exercises may be devised to develop students' sensitivity to the variety of media, grounds, and their combinations in order to produce drawn equivalences for these perceptual experiences, equivalences which may then be employed as poetic devices in the communication process: 


\section{Communication}

...we may have to allow for a greater degree of subjectivity in reading a visual message than a verbal one. This is not to excuse the lack of explicit theory about such issues in art history, criticism and teaching. (O’Toole 2005: 89)

The pioneer of visual semiotics Michael O'Toole's gentle chiding of the pedagogical artworld's reluctance to theorise its practices has stimulated the effort to articulate the processes of visual communication by adapting a systemic-functional semiotics of language. Whilst such terminology might appear rather too 'scientific' for some, I would argue that this means of scrutiny which allows visual works to be construed (and constructed) as rational expressions of cultural meanings, amenable to rational accounts and analysis, empowers students of the visual arts, as it has students of the language-based artforms for decades. The efficacy of systemic-functional semiotic theory first proposed by the socio-linguist Michael A.K. Halliday $(1973,1978)$ as applied to the study of languages is well-established; its usefulness as a means of negotiating meanings related to cultural context in the fields of visual communication is still burgeoning... (Kress and Van Leeuwen 2006; O'Toole 2011; Roberts and Riley 2012; Hughes and Riley 2013; Riley 2014).

Halliday theorised three functions of language in a social context, identifying:

The ideational function...is the content function of language, language as 'about something'. This is the component through which the language encodes the cultural experience, and the speaker encodes his own individual experience as a member of the culture. It expresses the phenomena of the environment: the things - creatures, objects actions, events, qualities, states and relations - of the world and of our own consciousness... (Halliday 1978: 108)

Secondly, an interpersonal function, through which...

...the speaker intrudes himself into the context of situation, both expressing his own attitudes and judgements, and seeking to influence the attitude and behaviour of others. (Halliday 1978:108) 
And thirdly, a textual function which facilitates both the ideational and interpersonal functions and renders them coherent. It also...

...expresses the relation of the language to the environment, including both the verbal environment - what has been said and written before - and the nonverbal, situational environment. (Halliday 1978:108)

Halliday's insights have been adapted to visual modes of communication by O'Toole (2011):

It is my contention...that semiotics - the study of sign systems - can assist us in the search for a language through which our perceptions of a work of art can be shared. I believe that we should start with the impact the particular work has on us as we view it...but this semiotic approach will also allow us to relate the nature of this impact to the scene portrayed, the social, intellectual, and economic world within which the artist and his patrons worked, or our own, and to incorporate ways of talking about composition, technique, and the material qualities of the work. (O'Toole 2011: 10)

My own contention is that an understanding of visual semiotics not only empowers art students' ability to negotiate, articulate and therefore share meanings of existing artworks, but can also empower their practice by facilitating an understanding of how the process of composition - the selection of visual elements and their combination according to (or in defiance of!) conventions of the appropriate visual code(s) - may position viewers of the work in terms of their mood and attitude towards whatever is represented in the work. This is the crux of this article's usefulness to students of drawing and their tutors: a clear articulation of visual semiotic theory which can be applied in studio teaching to underpin practical procedures in the production of work relevant to a specific cultural context.

Table (i) maps the domain of drawing as a matrix of the social Functions of drawing and the various Levels of Engagement at which one might enter negotiation with a drawing. Each cell of the matrix contains the Systems, or various ranges of choices relative to the functions, and which are available to the student, either as analyst of existing work, or as composer of original work. Hence the term Systemic-Functional semiotic model! 
Despite its rather rigid appearance, the matrix provides students with a flexible domain of

possibilities, to be negotiated according to the student's individual direction of exploration.

\begin{tabular}{|c|c|c|c|}
\hline 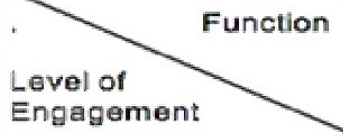 & $\begin{array}{l}\text { EXPERIENTIAL } \\
\text { (whot Is represented: } \\
\text { experlences of the world) }\end{array}$ & $\begin{array}{l}\text { INTERPERS ONAL } \\
\text { (baw the viewer is } \\
\text { positioned in terms of } \\
\text { mood and attitude) }\end{array}$ & $\begin{array}{l}\text { POETIC } \\
\text { |(how perceptual and } \\
\text { emotlonal experiences } \\
\text { are represented) }\end{array}$ \\
\hline Drawing as D/splayed & $\begin{array}{l}\text { Proxima: Perceptual } \\
\text { Values. } \\
\text { Theme } \\
\text { Narrative } \\
\text { Genre } \\
\text { Representatlonal/abstract } \\
\text { Interplay of Episodes. }\end{array}$ & $\begin{array}{l}\text { Attltude, Modality: } \\
\text { Intimate/Monumental } \\
\text { Public/Prlvate } \\
\text { Active/Passive } \\
\text { Rhythm//ocal points: } \\
\text { Dynamic/Static } \\
\text { Calm/Agitated }\end{array}$ & $\begin{array}{l}\text { Overall format and } \\
\text { slze. } \\
\text { Gestalt relations: } \\
\text { horizontals, verticals, } \\
\text { dlagonals. } \\
\text { Framing devlces. } \\
\text { Colour, pallette. } \\
\text { Systems of Geometry: } \\
\text { perse, ortbe, axe. etc. }\end{array}$ \\
\hline $\begin{array}{l}\text { Eplsodes of the } \\
\text { Drawing }\end{array}$ & $\begin{array}{l}\text { Distal Perceptual Values } \\
\text { Primary Geometry (layout } \\
\text { of surfaces and edges) } \\
\text { Actions, events central to } \\
\text { narrative. } \\
\text { Dlstance between } \\
\text { Surfaces in the Scene. }\end{array}$ & $\begin{array}{l}\text { Position relative to } \\
\text { scene,(Orientation of } \\
\text { viewer). } \\
\text { Gaze/eyework. } \\
\text { Modality: } \\
\text { happy/gloomy, } \\
\text { calm/excited eic. }\end{array}$ & $\begin{array}{l}\text { Secondary Geometry: } \\
\text { (perspective/non } \\
\text { perspective } \\
\text { projections). } \\
\text { Interplay of } \\
\text { figures/passages } \\
\text { Contrast of tone/texture }\end{array}$ \\
\hline $\begin{array}{l}\text { Combinations of } \\
\text { Marks } \\
\text { (sub-assemblles) }\end{array}$ & $\begin{array}{l}\text { Haztle Perceptual Values } \\
\text { Edges: occlusion of } \\
\text { surfaces } \\
\text { Direction } \\
\text { Transparency/opacity } \\
\text { Atmosphere } \\
\text { Time of day }\end{array}$ & $\begin{array}{l}\text { Sense of } \\
\text { 'affordances' in the } \\
\text { scene. } \\
\text { Heavy/lightweight } \\
\text { Flatness/illuslons of } \\
\text { depth }\end{array}$ & $\begin{array}{l}\text { Textural Qualities of } \\
\text { Medla/Ground. } \\
\text { Relative Fositions of } \\
\text { Marks. } \\
\text { Relative Sizes of } \\
\text { Marks. } \\
\text { Dlvision of Picture- } \\
\text { Plane: ratios, angles. } \\
\text { Overlap of } \\
\text { shapes/tones }\end{array}$ \\
\hline Individual Marks & $\begin{array}{l}\text { Effects of light on } \\
\text { surfaces in the } \\
\text { environment. } \\
\text { Spatial Depth. } \\
\text { Scene Primltives. }\end{array}$ & $\begin{array}{l}\text { Sense of textural } \\
\text { differences. } \\
\text { Indices of mark- } \\
\text { maker's movements: } \\
\text { speed, pressure. }\end{array}$ & $\begin{array}{l}\text { Position and Size of } \\
\text { Marks within Picture } \\
\text { Plane. } \\
\text { Interaction between } \\
\text { Medlum and Surface. } \\
\text { Picture Primitives. }\end{array}$ \\
\hline
\end{tabular}

Table (i) A Systemic-Functional Semiotic Model of the Domain of Drawing.

In this model, Halliday's 'ideational' function becomes the Experiential, relating to our visual, emotional and imaginational experiences of the world; his 'interpersonal' function remains appropriate for describing the modal relations between drawer and viewer, and Halliday's 'textual' function is termed the Poetic, in the specific sense of that word defined by the Russian linguist Roman Jakobson's (1960) insight as to how poetic devices rhetorical tropes, for example - serve to foreground, to draw the viewer's attention to the aesthetic form of the work itself, regardless of experiential content. The notion of poetic devices in literature is well understood, and an equivalence can be drawn with the process of 
communication through drawing: the selection and combination of the visual elements - line, tone, shape, texture and colour - in order to produce contrast, proportion, scale, pattern and rhythm, which visually represent both our experiences of the visual world as well as abstract concepts which may be represented in drawings through the use of metaphor, metonym, synecdoche and other poetic devices.

\section{Theory into Practice}

To reiterate: the main point I wish to make is that an awareness of the systems of compositional choices available under the Poetic function can empower students' practice, provided they have aims in mind about how they want to represent experiences (visual, emotional, imaginative), thus prompting viewers with opportunities to position themselves in terms of mood and attitude in relation to the experiences represented. Such awareness, instilled through consistent tuition, soon becomes intuition.

I shall focus upon the Poetic Function, involving compositional decisions affecting the construction of drawings, since the aim of this article is to argue for the efficacy of the systemic-functional semiotic model as a catalyst of production, rather than the more established means of negotiating meanings from existing artworks which O'Toole has demonstrated so effectively.

....an artist has at his or her disposal various devices for engaging our attention, drawing us into the world of the painting, and colouring our view of that world. And he or she does this for all viewers. In the grammar of painting - that is, all those aspects of structure that we all share - these devices fulfil a Modal function - and however much our ultimate interpretations may differ, I want to claim that the responses evoked in us by the systems of this function are virtually universal. One might say that they provide the 'baseline' for more individual conceptions and flights of fancy. (O'Toole 2011: 11)

O'Toole's argument for painting applies to drawing equally, his Modal function the equivalent of the Interpersonal in Table (i). The 'various devices' and how they might 
position viewers in relation to the drawings' content are now discussed in a demonstration of how the model can facilitate the production of drawing.

I have chosen not to demonstrate the transformation of perceptual experiences into visual equivalents normally composed in representational drawing, but to take on the challenge of finding visual compositional devices to convey an abstract proposition: the general Theme, Drawing Preceded Writing, is stimulated by the argument that our innate drive for structuring the chaos we perceive into ordered codes through which we make sense of the world, has been sustained by our ability for visual depiction which eventually led to the emergence of symbolic codes such as writing.

As archaeologist Iain Davidson and psychologist William Noble, working collaboratively on the early cave drawings as indicators of the origins of symbolic languages, put it:

A further matter eventually arises from the recognition of depiction as depiction, namely, the possibility of a meaning's being given to something which is not depictive. We call this a code. (Davidson and Noble 1989:131)

A series of six drawings (Figure 1) by the author, titled Drawing Over Writing 1-6 was first exhibited in the Opus Group show What Will Be Seen, at the BayArt Gallery, Cardiff, June 2010. 


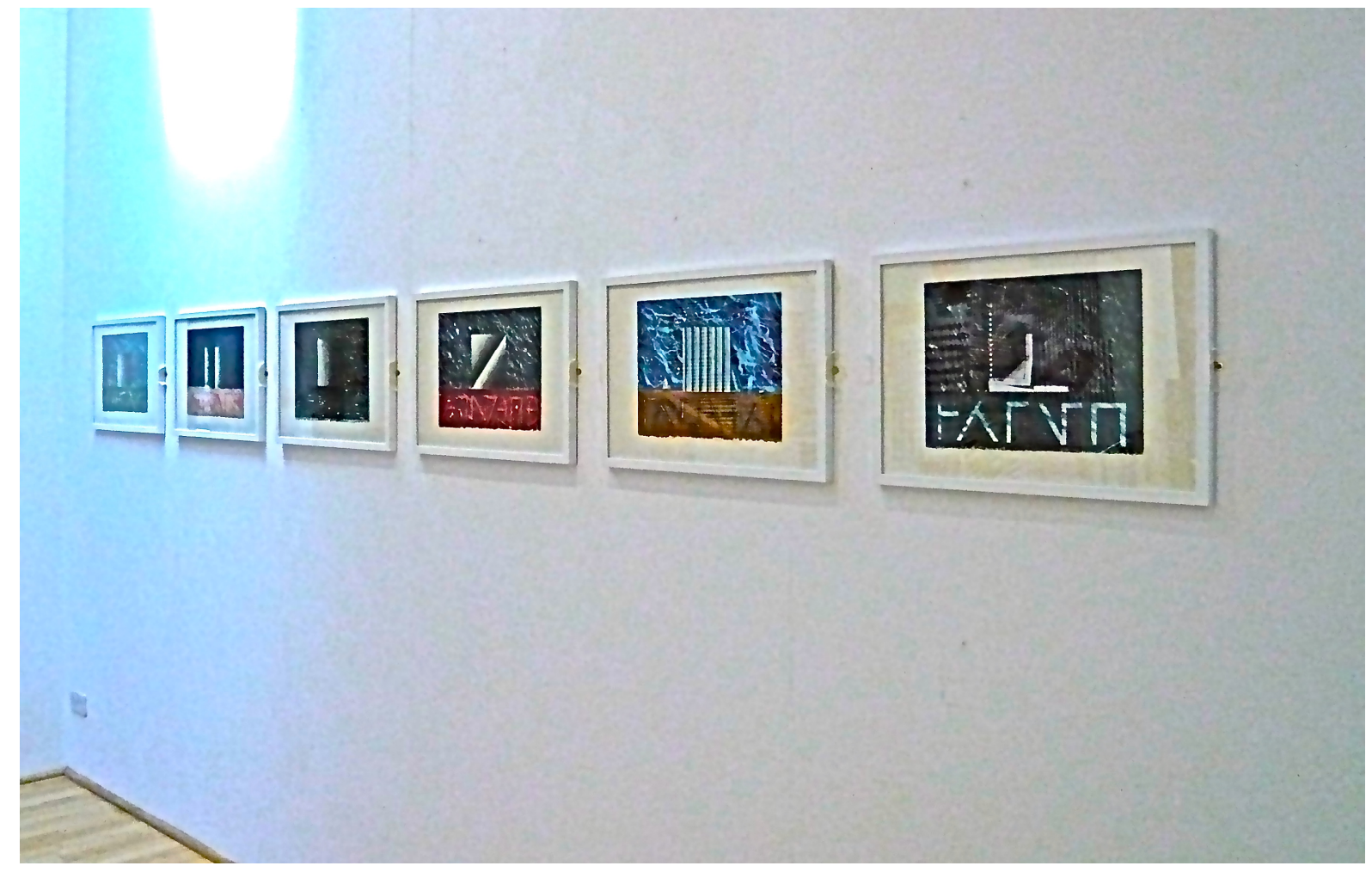

Figure 1 Howard Riley Installation view of Drawing Over Writing series of drawings. 


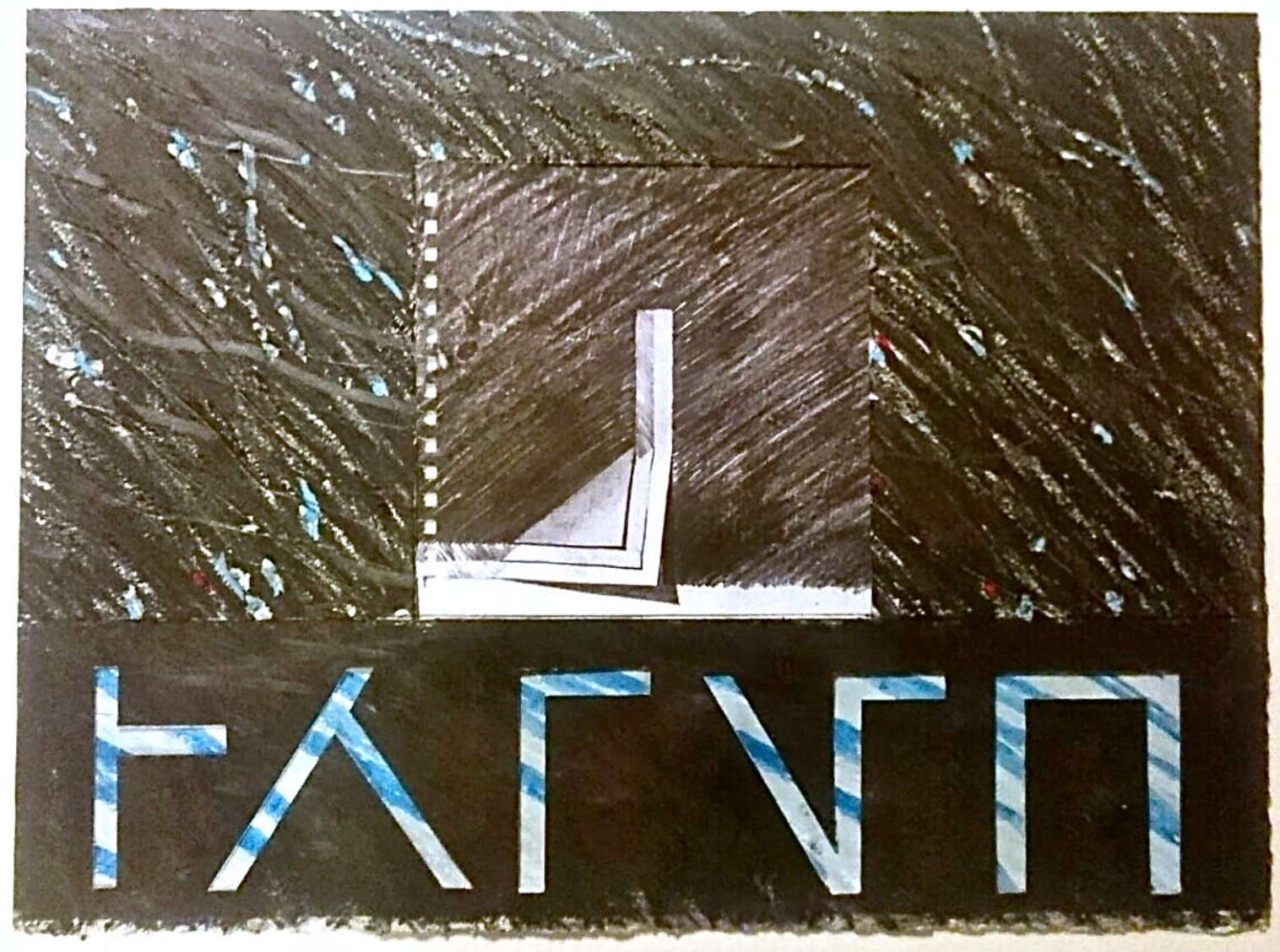

Figure 2 Howard Riley Drawing Over Writing 6. Oil pastel, graphite, charcoal on Saunders Waterford 300gsm A3 paper

It may be useful to employ the template of Table (i) to illustrate an example of the specific choices made in the composition of a specific drawing, and to show how those selections relate to the potential effects upon viewers' mood and attitude towards what is represented in the drawing.

Table (ii) below, sets out the choices made within the Poetic function at each Level of Engagement, and related to the Interpersonal and Experiential functions. In deference to the convention of reading English from left to right, I have positioned the Poetic function - the function dealing with the selection and combination of drawn visual elements - to the left, in order to prioritise the activities of the producer of the work. 


\begin{tabular}{|c|c|c|c|}
\hline $\begin{array}{l}\text { FUNCTION } \\
\text { LEVEL OF } \\
\text { ENGAGEMENT }\end{array}$ & $\begin{array}{l}\text { POETIC FUNCTION } \\
\text { How perceptual and } \\
\text { emotional } \\
\text { experiences are } \\
\text { realised in visual form }\end{array}$ & $\begin{array}{l}\text { INTERPERSONAL } \\
\text { FUNCTION } \\
\text { How the viewer is } \\
\text { positioned in terms of } \\
\text { mood and attitude }\end{array}$ & $\begin{array}{l}\text { EXPERIENTIAL FUNCTION } \\
\text { What is represented: } \\
\text { Experiences of the world }\end{array}$ \\
\hline $\begin{array}{l}\text { Drawing as } \\
\text { Displayed }\end{array}$ & $\begin{array}{l}\text { Format, Size: } \\
\text { Landscape, A3 } \\
\text { Framing: Plain white } \\
\text { Lighting: Under } \\
\text { gallery control } \\
\text { System of Geometry: } \\
\text { Orthographic } \\
\text { projection }\end{array}$ & $\begin{array}{l}\text { Small size, positioned } \\
\text { at eye-level, draws } \\
\text { viewer into the picture. } \\
\text { Modality: Connotations } \\
\text { of balance, symmetry. } \\
\text { Viewer positioned } \\
\text { close to foreground. } \\
\text { Gaze: Central focal } \\
\text { point draws viewer's } \\
\text { gaze. Connotations of } \\
\text { layered structure. } \\
\text { Viewer positioned in } \\
\text { front of a 'corridor of } \\
\text { space' }\end{array}$ & $\begin{array}{l}\text { Proximal values. } \\
\text { Theme: 'Drawing } \\
\text { Precedes Writing.' Our } \\
\text { facility for depiction } \\
\text { preceded, facilitates } \\
\text { writing. }\end{array}$ \\
\hline $\begin{array}{l}\text { Episodes of the } \\
\text { Drawing }\end{array}$ & $\begin{array}{l}\text { Interplay of passages: } \\
\text { Gestalt Relations: } \\
\text { Rectilinear } \\
\text { compositional } \\
\text { elements }\end{array}$ & $\begin{array}{l}\text { Sense of progression } \\
\text { from background to } \\
\text { foreground. }\end{array}$ & $\begin{array}{l}\text { Distal values. } \\
\text { Background: Chaos } \\
\text { Middle ground: stability, } \\
\text { order } \\
\text { Foreground: Arbitrary } \\
\text { symbols }\end{array}$ \\
\hline $\begin{array}{l}\text { Combinations of } \\
\text { Marks }\end{array}$ & $\begin{array}{l}\text { Contrast boundaries: } \\
\text { Tonal and textural } \\
\text { boundaries }\end{array}$ & $\begin{array}{l}\text { Viewer sense of } \\
\text { position in the pictorial } \\
\text { space. Viewer reads } \\
\text { contrast boundaries as } \\
\text { occluding surfaces, } \\
\text { reinforces sense of } \\
\text { depth. }\end{array}$ & $\begin{array}{l}\text { Spatial depth: from } \\
\text { background to } \\
\text { foreground, rough to } \\
\text { smooth. }\end{array}$ \\
\hline Individual Marks & $\begin{array}{l}\text { Background: loose, } \\
\text { rough, random, } \\
\text { uncoordinated. } \\
\text { Middle ground: Even } \\
\text { texture, contrast } \\
\text { boundaries. } \\
\text { Foreground: Clear, } \\
\text { precise symbols. }\end{array}$ & $\begin{array}{l}\text { Marks indicate erratic } \\
\text { speed and pressure. } \\
\text { Marks indicate more } \\
\text { controlled modality. } \\
\text { Viewer intrigue: } \\
\text { meaningful symbols? }\end{array}$ & $\begin{array}{l}\text { Haptic values. } \\
\text { Range of textures, } \\
\text { contrast boundaries } \\
\text { indicate edges in the } \\
\text { visual field. } \\
\text { Alphabetic code? }\end{array}$ \\
\hline
\end{tabular}

Table (ii) Systemic-Functional Choices informing Figure 2 Drawing Over Writing 6 


\section{Discussion}

Addressing each Level of Engagement, from the general view to the level of specific details: Level of Engagement: Drawing as Displayed

The choices of A3 size in landscape format, and plain white frames fixed at eye level upon a white wall invite viewers into the pictorial spaces with little distraction from the surroundings (apart from the vagaries of lighting, (dictated by the gallery architecture rather than by any controlled decision!)

The Theme outlined earlier, running through the sequence of drawings (Figure 1) implies a movement from chaos to order: a visual equivalent for such movement may be depicted through a familiar Western convention of picture-making; the shift from a distant background (the upper portion of the picture-plane) through a central structuring device constructed of visual elements connoting balance, stability and complex layering, to a close-up foreground (the lower portion of the picture-plane).

An awareness of the Systems - the ranges of compositional choices available from the paradigms of visual elements; line, tone, shape, texture, colour - together with the possibilities of their various combinations informs the selection of roughly-textured, unstructured blue and black marks in Figure 2 to connote a background of deep chaos, contrasted with the clean-edged, precisely-ordered symbols in the foreground, connoting the emergent order of written codes, but, note, symbols through which flecks of the blue/black background marks are still evident: the code is transparent...

Level of Engagement: Episodes of the Drawing

When the viewer engages with each of these drawings at the level of Episodes of the Drawing, then a pattern emerges which is common to them all: the central position of the square, resting on a horizontal line effectively dividing background from foreground, connotes physical stability and epitomises visual balance. Metaphorically, the square offers 
interpretation as representing the dependability of our structuring capacity; through this constant compositional structure, the variety of transformative changes from chaos to order is implied in each of the sequence of drawings.

\section{Level of Engagement: Combination of Marks}

At the level of engagement Combinations of Marks, the choice of high-contrast boundaries between the rectilinear shapes represent edges in the visual field, and the selection of textural gradients and tonal gradients produce illusions of surface depths, so that the viewer is invited through the picture - plane, emphasising the effect of spatial distance.

\section{Level of Engagement: Individual Marks}

At this level, choices of media and drawing-surface are prioritised, and become the first decisions made in the process of production. The paper selected has a robust 'key', a surface characteristic affording a wide range of textural effects in combination with a variety of media - oil pastel, charcoal and graphite. The careful selection of marks varying in scale and texture enhances the illusions of depth from background to foreground in each drawing, and allows the viewer to infer a distinction between chaos and order.

\section{Summary}

Language itself appears to have emerged from a background world of visual ambiguity, via our innate capacity for structuring chaos into order, and has permeated our observations of the material world to such an extent that the two have become one. Language is the filter through which we perceive the world, it becomes transparent, interwoven with our perception of the fabric of the material world, yet its visible form - writing - remains forever arbitrary, forever open to negotiation.

After all, as Edward Sapir (1929: 162) pointed out: 'We see...very largely as we do because the language habits of our community predispose certain choices of interpretation.' Or, more 
poetically, (since we are foregrounding the poetic function!), as the Russian Futurist Velimir Khlebnikov (1913) exclaimed 'Look! The sun obeys my syntax.'

\section{Concluding Comment}

The conference presentation upon which this article is based ended with a recommendation for the reconsideration of the '3 Rs': Reading, Routing, 'Rithmetic, where Routing represents our age-old facility for mark-making on surfaces, a visualcy, to coin a term, that both preceded and facilitated the rather more familiar literacy and numeracy...

A visualcy evidenced by an intelligence of seeing informed by an ability to change channels of perception, and to devise drawn equivalents for those perceptual, emotional and imaginational experiences structured through an understanding of the systemic-functional semiotic model, so that students' practice may be empowered, not only through drawing, but ultimately through whatever media or production processes are deemed appropriate for the work undertaken.

\section{References}

Davidson, I. and Noble, W. (1989) The Archaeology of Perception, Current Anthropology, Vol. 30, No. 2, pp125-137.

Gibson, J. J. (1979) The Ecological Approach to Visual Perception. Boston: Houghton Mifflin.

Halliday, M.A.K. (1973) Explorations in the Functions of Language. London: Edward Arnold.

Halliday, M.A.K. (1978) Language as Social Semiotic: The Social Interpretation of Language and Meaning. London: Edward Arnold.

Halverson, J. (1992) The First Pictures: Perceptual Foundations of Paleolithic Art, Perception. Vol.21, pp389-404.

Hughes, A.U. and Riley, H. (2013) Towards a Multimodal Model for the Teaching and Production of Narrative Film, in E. Montagna (Ed.) Readings in Intersemiosis and Multimedia, Como/Pavia: Ibis. pp133-147.

Husserl, E. (1970) [1913] Logical Investigations, New York, NY: Humanities Press. Jakobson, R. (1960) Closing Statement at the Conference on Style in Language: Linguistics and Poetics, in T.A. Sebeok, [Ed.] Style in Language, New York: Wiley.

Kennedy, J.M. and Silver, J. (1974) The Surrogate Functions of Lines in Visual Perception: Evidence from Antipodal Rock and Cave Artwork Sources, Perception, Vol.3, pp313-322. Khlebnikov, V. (1913) Decrees to the Planet, in G. Steiner (1975) After Babel. Aspects of Language and Translation, London: Oxford U.P. p246.

Koestler, A. (1975) The Act of Creation. London: Pan Books. 
Kress, G. and Leeuwen, T. van (2006) Reading Images. The Grammar of Visual Design (2 ${ }^{\text {nd }}$ ed.) Routledge: London.

O'Toole, M. (2005) Pushing Out the Boundaries: Designing a Systemic-Functional Model for Non-European Visual Arts, in Linguistics and the Human Sciences, Vol. 1, No. 1, pp83-97.

O'Toole, M. (2011) The Language of Displayed Art, 2nd ed. London: Routledge.

Riley, H. (2008) Drawing: Towards an Intelligence of Seeing, in S. Garner (Ed.) Writing on

Drawing, Bristol/Chicago: Intellect/University of Chicago. pp153-167.

Riley, H. (2014) Analysing Pictures: A Systemic-Functional Semiotic Model for Drawing, in Maiorani, A. and C. Christie (Eds.) Multimodal Epistemologies: Towards an Integrated

Framework. (Routledge Studies in Multimodality). London: Routledge. pp83-93.

Roberts, A. and Riley, H. (2012) The Social Semiotic Potential of Gestural Drawing, Journal of Visual Art Practice, Vol.11, No. 1, pp63-73.

Sapir, E. (1929) The Status of Linguistics as a Science, in D.G. Mandelbaum (1949) Selected Writings in Language, Culture and Personality, Berkeley, CA: University of California

Press. p162.

Segall, M.H., Campbell, D. and Herskovits, M. J. (1966) The Influence of Culture on Visual

Perception. Indianapolis, IN and New York, NY: Bobbs-Merrill.

Viollet-le-Duc, E-E. (1879) Histoire d'un Dessinateur. Paris: J. Hetzel.

Witkin, R.W. (1995) Art \& Social Structure. Cambridge: Polity Press.

\section{Biographical Note}

Howard Riley PhD MA(RCA) CertDes FRSA FHEA, Emeritus Professor, Swansea College of Art, Wales, UK, studied at Hammersmith College of Art, Coventry College of Art, and the Royal College of Art. He holds a doctorate of the University of Wales in the practice and pedagogy of drawing. He taught at various art schools in London before taking up a post in the School of Art and Design, Curtin University, Perth, Western Australia, where he studied with Professor Michael O'Toole, a pioneer of visual semiotics at Murdoch University in Perth. He has published in the areas of drawing pedagogy, visual semiotics, generative art and multimodality. His drawings have been exhibited in Australia, Malaysia, Finland, Serbia, the USA and the UK.

howard.riley@btinternet.com 